\title{
Managing Higher Education Needs of Internally Displaced Persons in Cross River State, Nigeria
}

\author{
Mary Anike Sule ${ }^{1}$, Ovat Egbe Okpa ${ }^{1}$, Francisca Nonnyelum Odigwe ${ }^{1}$, Joseph Udida Udida ${ }^{1}$ \& Ikpi Inyang Okoi ${ }^{1}$ \\ ${ }^{1}$ Department of Educational Management, University of Calabar, Nigeria \\ Correspondence: Ovat Egbe Okpa, Department of Educational Management, University of Calabar, Calabar, \\ Nigeria. E-mail: okpaovat@gmail.com
}

Received: March 4, 2020

doi:10.5539/ies.v13n11p10
Accepted: July 11, $2020 \quad$ Online Published: October 9, 2020

URL: https://doi.org/10.5539/ies.v13n11p10

\begin{abstract}
Displaced persons encounter some difficulties in accessing higher education, yet higher education remains their inalienable rights. This study focused on ways of managing the higher education needs of internally displaced persons. Three hypotheses guided the study. The descriptive survey research design was adopted in the study. The entire population was used since it is not large enough to warrant randomization. The sample comprised 600 participants (38 teachers and 562 senior secondary (SS 1-3) students from three secondary schools. The instrument used for data collection was questionnaire titled Higher Education Needs for Displaced Persons Questionnaire (HENDPQ) on a modified four point Likert scale. The precision and internal consistency of the instrument was determined using Cronbach reliability method which gave rise to a coefficient ranging from $0.76-0.81$. The data was collected personally by the researchers with the help of three research assistants. The data collected was analyzed using Pearson Product Moment Correlation Analysis at 0.05 level of significance. The result of the analysis revealed that there is a significant positive influence of higher education needs on development of displaced persons, provision of scholarships/bursaries on access to higher education; and provision of certified distance learning and e-learning opportunities on access to higher education for displaced persons. Based on these findings it was recommended that the government should urgently manage the higher education needs of displaced persons through adequate provision of scholarships/bursaries, distance learning and e-learning opportunities to enhance access to higher education.
\end{abstract}

Keywords: managing, higher education needs, internally displaced persons

\section{Introduction}

In Nigeria as elsewhere, internally displaced persons are the most vulnerable group and are susceptible to all forms of exploitation and neglect for the obvious reasons. An internally displaced person (also known as "IDPs") has been legally defined by UNHCR (2015b) as "an individual forced to flee from his/her home or place of habitual residence, as a result of or in order to avoid the effects of armed conflict, situations of generalized violence, violations of human rights or natural or human-made disasters, who has not crossed an internationally recognized state border." Large numbers of IDPs are visibly scattered across different states in Nigeria without a reliable database providing a comprehensive profile of the IDPs. Nigeria is reported to have the largest population of displaced people in Africa, over 3.3 million IDPs (UNHCR, 2020). The cause of displacement in Nigeria is multi-faceted and sometimes complex. It ranges from flooding, religious conflict, ethnic violence, insurgency, militancy, kidnapping, banditry, Fulani pastoralist and farmers conflict and terrorism by the militant Islamic group Boko Haram. About 2.6 million people have so far been displaced from their homes in northern-eastern Nigeria due to frequent attacks by Boko Haram (IDMC, 2019).

Bakassi people in Cross River State, Nigeria were displaced following the World Court judgment of October 10, 2002 and Green Tree Agreement of June 12, 2006 that ceded the oil rich peninsula to Cameroun. Over 400,000 Bakassi returnees were internally displaced from the oil rich Bakassi Peninsula (FRN, 2012). The ownership of the contentious piece of land was ceded to Cameroun. It is about 18 years down the line that Nigerian citizens who once claimed the Bakassi Peninsula as their homeland are yet to be properly resettled (Usang, Ikpeme, \& Amimi, 2014; Punch, 2016) in spite of government's huge resources committed to the area; majority of the people are poor and under fed, the settlers are without good drinking water, no access to good education and poor health delivery services. The people have grudgingly borne the tag of displaced people since they chose to be citizens of Nigeria. 
They have lost their means of livelihood and have remained homeless. The population is increasing on a daily basis without commensurate facilities to cater for their welfare. Children born in 2002 when the Bakassi was ceded to Cameroun are now about 18 years old and should in the next few years be preparing for life in tertiary institutions of learning. But this is not the case. What future is there for them if they cannot be given basic and sound education to enable them to function optimally in an increasing competitive world?

According to UNHCR (2016) access to higher education or skills-based education among displaced persons is still very low due to some barriers like shortage of space, lack of documentation (birth certificate, school leaving), school fees, lack of transportation and security concerns. Education is an essential and inalienable right of citizens especially for IDPs to prepare them for life, for employment and for participation in community development and governance. Education remains an important aspect of our lives and it is vital to our development, our understanding and our personal and professional growth. Education also builds knowledge and skills for self-reliance and resilience. It can also contribute to peace and security and mitigate factors responsible for conflict and displacement (UN Refugee Agency (UNHCR), 2016). World Bank (2018) harping on the benefits of education stated that "providing students with basic cognitive skills could massively boost economic outcomes, especially in developing countries". In an emergency situation such as displacement, education gives hope and reduces the trauma already suffered (Okwute, Sanda, \& Usman, 2017). The researchers maintained that education provides lifesaving and life sustaining physical, psychosocial and cognitive protection. It offers safe space for learning as well as ability to identify and provide support for affected individuals, particularly for children and adolescents. Education mitigates the psychosocial impact of conflict and disaster by giving a sense of normality, stability (Ferris and Winthrop 2010) and it saves lives, provide children with lifesaving information as well as sustain the progress already made by communities.

Parents and children who are better educated tend to be healthier, more empowered in their lives and communities, and more tolerant and resolution-seeking. This is why the demand for access to higher education continues unabated due to its social benefit, especially in a society in which social mobility depends largely on the level of education acquired and where a competitive marketplace have made a university or college education vital to advancement in many professions and meeting the needs of a globalized economy.

Displaced young people miss out on months or years of education, and this is damaging to them and their families, as well as to their societies, both in the short and long term. The Bakassi youths like other refugees have high educational aspirations and strongly value education as means of restoring their dignity, security and hope (Lenette, 2016). Lack of higher educational opportunities stifles youth development and limits the chances of channeling their potentials to contribute to their families and communities throughout their lifetimes. Access to higher education serves as a channel to address other basic needs and is critical in reducing conflict and its effects on individuals, societies and should be an integral part of humanitarian response and future development efforts (El-Sheikh, 2017). It provides employment and is required for desirable jobs. The Universal Declaration on Human Rights (Article 26) specifies that higher education shall be equally accessible to all on the basis of merit in conflict affected countries and among displaced populations; but access to education, particularly higher education is often seriously affected. In Bakassi as in other places of conflict, accessing the right to education is fraught with severe challenges ranging from inadequate educational infrastructure, capacity and resource constraints to persistent insecurity, social tensions and discrimination. Girls and boys also face their own specific barriers. Girls are often expected to stay at home and support their families by taking care of their siblings, particularly if they are the eldest child, which puts greater pressure on them to drop out of school. Early or forced marriage and pregnancy are also barriers, some parents send their daughters off to be married or cared for by another family. Boys are often obliged to work to supplement their families' income rather than go to school and may also face the risk of forced recruitment.

\subsection{Statement of the Problem}

The importance of higher education to displaced persons cannot be over stated. It has the potential of acting as a catalyst for effective and sustainable recovery (Milton \& Barakat, 2016). Displaced youth with higher education skills contribute to the promotion of peace, social cohesion and development among communities. They foster leadership and serve as role models to encourage other youths who enroll in schools to remain and complete their education cycle, thus helping to prevent or minimize negative tendencies. Displaced persons with higher education qualification serve as key drivers of peace-building initiatives among communities. If displaced people received higher education, they are more likely to develop necessary skills to make use of in the existing economic, social, and political systems in their host communities.

A large number of Bakassi youth of university age (18-24) have been displaced. Most of them do not have access to 
quality education that provides physical protection and personal capacity development. Although there are very few displaced people currently seeking places in higher education institutions in Cross River State, it is nevertheless important to reflect on their higher education needs and consider what should be done to address the problem where possible. The demand for higher education among Bakassi displaced people continues to outweigh the supply. Although some progress has been made in terms of providing access to primary and secondary school, access to and retention of displaced people at higher education level remains a challenge. Basic education alone will not meet the requirements of a globalized world in which secondary and tertiary education will be necessary. The youth have the ability and drive for higher education, but their educational path has been interrupted by displacement. This has created gaps which are difficult to fill and for which additional support is needed. There must be an effort to grow a stock of highly skilled human capital and, by extension, expand national (largely economic) capacity. Denying them higher education opportunities may result in loss of human resources and increased pauperization of the people. There is scanty information on any standardized structure, well-articulated plans and procedure in Nigeria that can cater for education needs in emergencies (Ajayi \& Awodiji, 2016). It is against this backdrop that this study intends to investigate how higher education needs of displaced persons can be managed to enhance access to higher education among Bakassi people of Cross River State.

\section{Literature Review}

\subsection{Higher Education Needs and Development of Displaced Persons}

The value attached to higher education is that it is a driver of individual social mobility and national economic development (Altbach, Reisberg, \& Rumbley, 2009). The former UN Secretary General, Koffi Anan in Delgado (2008) argued that university education can help to develop African expertise; it can enhance the analysis of African problems and strengthen domestic institutions; serve as a model environment for the practice of good governance, conflict resolution and respect for human rights and enable African academics to play an active part in the global community of scholars for peace building. This position points to the strategic role higher education has to play in repositioning the youths for peace building and development of their communities.

Higher education refers to all post-secondary school learning. It includes structured learning in a range of settings, including workplaces, universities, and colleges of Education, polytechnics/monotechnics and Innovative Enterprise Institutions. The National Policy on Education (FGN, 2004), defines tertiary education(higher education) as the Post-Secondary Section of the National education system, which is given in Universities, Polytechnics and Colleges of Technology including courses as are given by the Colleges of Education, Advanced Teachers Training colleges, Correspondence Colleges and vocational training institutions, either public or private, offering qualifications at different levels and of differing length through formal education programmes either on-site, at distance or in a blended format. In Nigeria therefore, higher education is one that is given at the higher educational institutions for the purpose of producing specialized middle and high level manpower needed to effect positive changes and national development (NPE 2004). The National Policy on Education (NPE, 2004, 4th Edition) in section 8 , specifically subsection 59 states that the goals of higher education shall be to:

a) Contribute to the national development through high level relevant manpower training;

b) Develop and inculcate proper values for the survival of the individual society;

c) Develop the intellectual capability of individuals to understand and appreciate their local and external environments;

d) Acquire both physical and intellectual skills which will enable individuals to be self-reliant and useful members of the society;

e) Promote and encourage scholarship and community service;

f) Forge and cement national unity; and

g) Promote national and international understanding and interaction.

Those who receive higher education degrees, diplomas and certificates are open to improved economic opportunities and incomes that can support entire families. It encourages children who are still in secondary schools to stay in school, thus reducing the rate of dropout.

Access to higher education plays a critical role in the peaceful rebuilding of societies as well as enhancing social and economic returns in post-conflict communities. Lowe (2019) maintained that access to higher education protects displaced youth and is critical to gaining the skills needed for economic self-sufficiency and recovering a sense of purpose and dignity. It is also an essential long-term and portable investment that provides displaced youth the skills and experience to contribute as leaders and peace builders within the society. Hence, investing in 
higher education, is investing in a future, it is investing in a long-term sustainable society. In the same vein, Parater (2015) stated that "the future security of individuals is inextricably connected to education and the transferable skills developed through schooling. The knowledge and capacities expanded through education are the building blocks of dignity that will ultimately help a person thrive."

Reiterating on the benefit of higher education to displaced persons, UNHCR Education Report (2016:1) stated succinctly thus, "highly educated refugees can become leaders in their communities, creating businesses and social enterprises, or building infrastructure as engineers, scientists and technology specialists. They can lobby for improvements to public services as politicians and campaigners, and demand a better future through education, employment, and the protection and nurturing of youth. In doing so, they support and contribute to peace and stability, at a local, national and regional level."

In the same vein Gladwell et al. (2016) stated that higher education is critical to displaced persons because it provides protection from harm, contributes to post-conflict reconstruction, promotes social, economic and gender equality, and empowers refugee communities; it serves as a strong incentive for students to complete studies at primary and secondary levels; it is a tool that helps develop the human and social capital necessary for future reconstruction and economic development in countries of origin. Providing higher education opportunities for displaced persons has the potential to limit the socio-economic burden and enable them to be more productive contributors to their host communities.

Protracted displacement is the biggest such hurdle, a major stumbling block to satisfying intellectual curiosity and leading a dignified life. This is due to the feeling of helplessness and insecurity that can compound feelings of despair and hopelessness over years of displacement with limited or no educational or economic opportunities. Many view higher education as a route out of poverty and discrimination and are highly aspirational and motivated (Moser-Mercer, Hayba, and Goldsmith, 2016). Provision of access to higher education will enable displaced persons build capacity for enhanced integration and contribution to their communities. It is therefore necessary to enhance opportunities to effectively educate displaced persons.

Investing in high quality higher education for displaced persons extends far beyond the time of displacement; it can clearly and directly contribute to post-conflict stabilization and recovery as well as protecting against exploitation and harm, including abduction, recruitment of children into armed groups and sexual and gender-based violence (Ferris \& Winthrop, 2010). Higher education increase access to higher-paying jobs, generates awareness of one's human rights and how to avoid exploitation, and promotes a more educated next generation (Grisanti, 2019).

\subsection{Provision of Scholarships and Bursaries Programmes and Access to Higher Education}

Transition from secondary school into higher education remains a problem for displaced youth especially in low income area like Bakassi. The cost of pursuing higher education therefore becomes a significant barrier for potential displaced learners. For most of them, economic hardship means that university or higher education fees are unattainable. Unless there are external sources of funding, such as scholarships and bursaries from a variety of sources like donations sent by relatives working in other countries, state/local government, Non-Governmental Organizations (NGOs), philanthropists, including corporations, professional associations and colleges and universities, dedicated to helping the displaced student achieve his or her educational goals, access to higher education will still be difficult. Higher education institutions too-through central administration or individual faculties or departments-can provide scholarship in the form of tuition waivers for displaced students or may make other lump-sum donations. Also, the private sector can be sensitized to support a scholarship programme through monetary donations or in-kind donations such as for accommodation, meals, clothing, books or other necessities. Governments can institute an official policy of waiving school fees for IDPs.

Cosentino, Fortson, Liuzzi, Harris, and Blair (2019) maintained that providing scholarships is an effective way to improve access to university studies and increase participation in tertiary education as well as promote social mobility among vulnerable, disadvantaged, and underserved youth in developing countries. Scholarships ensures that sponsored students are protected and given decent living conditions, which allow them to focus on their studies, build networks, and gain skills necessary to later succeed in the labor market. Scholarships programmes usually cover a wide range of costs, from tuition fees and study materials, to food, transport, and accommodation. Establishment of scholarship programmes to help fund higher education for IDP students remains one of the measures that can be adopted to close the educational gap and it is a key tool in increasing access to higher education. Scholarships offer sustainable access to higher education for displaced persons and are central in enabling young people in displaced communities continue studies beyond primary and secondary education and to build careers in competitive fields of employment (El-Sheikh, 2017).

Provision of scholarships enables displaced learners to study at existing established universities within the state or 
outside their immediate host community. Investing in higher education is investing in a future; it is investing in a long-term sustainable society (Bergan, 2015). She warned that offering short-term and emergency solution will contribute to suffering and increase their sense of insecurity. Scholarships should therefore be given to cover the duration of undergraduate and postgraduate studies and should not be tied to conditions such as the economic competitiveness of the home community, the degree of political freedom, the study level (postgraduate versus undergraduate) for the scholarships offered, academic discipline or field priorities/restrictions imposed by the scholarship programme. The scholarship should be aimed at giving the orphans and vulnerable children in the displaced communities hope and a brighter future by creating opportunities for them to acquire higher education in various disciplines of their choice.

\subsection{Provision of Certified Distance Learning Tertiary Education and E-Learning Opportunities}

The use of distance learning is one the strategies adopted by United Nations to expand access to open and distance higher education opportunities for displace persons and to close the gap between the need for higher education and its availability. According to Ambe-Uva (2012) distance learning education is an educational process in which teachers and learners are separated in space/and or time for some or all the study and in which learning materials take over some of the traditional role of the teacher. It normally occurs in a different place from teaching and as a result requires special techniques of course design, special instructional techniques, methods of communication by electronic and other technology, as well as special organizational administrative arrangements. Distance education, therefore, is the delivery of learning or training to learners who are separated, mostly by time and space, from those who are teaching and training. Distance learning and online-based programmes with open educational resources have become a key part of the strategy to increase access.

Provision of e-learning outside traditional academic setting is a valuable and an innovative way to bring flexible learning to displaced persons. Digital learning can be used to create opportunities for higher education for displaced persons. Such e-learning opportunities must take into account the specific needs of displaced person and academic degrees or certificates obtained through this process should be recognized by the relevant ministries and agencies. Online higher education for displaced persons through the use of blended learning approach to deliver their curricula, combining on-site tutoring and mentoring can prove to be of great value for refugees' pathways to higher education. Halkic and Arnold (2019) reported that online education and most notably Massive Open Online Courses (MOOCs) have been promoted by some higher education institutions and non-governmental initiatives as a solution for the integration of disadvantaged groups into higher education such as refugees. At first glance, the flexibility in time and place of studying online, no barriers as regards entry qualifications, and no tuition fees, seem to make online education an appealing offer to student groups regularly excluded from higher education programmes due to geographical, financial or entry qualification barriers. MENA (2016:5) reiterated that "given basic infrastructure, technology has the potential to deliver educational content at very low cost virtually anywhere, provide a curriculum and records system that can follow children on the move, reach those unable to attend school, link digital content to the national curricula of students' home country or their country of refuge, and certify educational achievement. Technology can also provide a means for teachers and other adults to receive pedagogical training, share materials and advice, and assess and document learning."

Inter-Agency Network for Education in Emergencies (INEE,2019) stated that Connected Learning Programme-an innovative pedagogical approach that leverages information technology to combine face-to-face and online learning, otherwise known as blended learning can be used to provide access to displaced persons. It enables students living in remote and mostly under-resourced areas to connect with higher education opportunities and to exchange knowledge globally. Higher education learning attainments for displaced persons should be certificated by the government and relevant ministries. This will make access effective and open up pathways for displaced persons into formal further education and job opportunities (INEE, 2016).

Although online higher education for displaced persons has several challenges-as with all ICT for education initiatives, the need for reliable infrastructure-electricity, sufficient computers, access to Internet it remains one of the strategies for expanding access to higher education to the isolated learners.

\section{Objectives of the Study}

The objectives of the study are:

1) To assess the higher education needs of displaced persons in Cross River State, Nigeria.

2) To find out how the provision of scholarships and bursaries awards influence access to higher education

3) To find out whether or not provision of certified distance learning tertiary education and e-learning opportunities will bridge the gap for access to higher education in the area. 


\section{Hypotheses}

1) There is no significant influence of higher education needs on the development of displaced persons.

2) Award of scholarships and bursary does not significantly influence displaced persons' access to higher education.

3) Provision of certified distance learning tertiary education and e-learning opportunities do not significantly influence displaced persons access to higher education.

\section{Methodology}

The study adopted a descriptive survey research design. Although not all secondary school-completers would have the academic ability or desire to access higher education, or be considered 'university-ready' displaced students and since no robust data on the potential number of 'university-ready' displaced youths was available, the researchers used all 38 teachers and 562 senior secondary (SS 1- 3) students from three secondary schools in Bakassi Local Government Area who are expected to make transition to higher education. The entire population was used since it is not large enough to warrant randomization. The instrument used for data collection was questionnaire titled Higher Education Needs for Displaced Persons Questionnaire (HENDPQ). The instrument had two sections A and B. Section A elicited demographic data of participants while section B consists 38 questionnaire items on a four point Likert scale designed to assess the higher education needs of displaced persons and ways of enhancing access to higher education. To ensure high validity, experts who know what should be measured from Measurement and Evaluation, Faculty of Education University of Calabar were made to review the content of the instrument. They were expected to assess the suitability of the language, the comprehensiveness, adequacy and relevance of items in addressing the research questions, bearing in mind the purpose of the study. Their opinion, comments, and corrections were used in the final form of the instrument before administration. The precision and internal consistency of the instrument was determined using Cronbach Reliability method which gave rise to a coefficient ranging from $0.76-0.81$. These figures were considered reliable for use in carrying out the study. The data was collected personally by the researchers with the help of three research assistants. The data collected was analyzed using Pearson Product Moment Correlation Analysis at 0.05 level of significance.

\section{Scope and Limitation of the Study}

The researchers are aware of the existence of other IDPs groups scattered all over Nigeria. This study is basically restricted to Internally Displaced Persons of Bakassi in Cross River State. The researchers focus has been on investigating into the management of higher education needs of the IDPs in Bakassi and how the provision of scholarships/bursaries and certified distance learning and e-learning opportunities can influence access to higher education for displaced persons. The subjects used for the study are the classroom teachers and SS 1-3 students from public secondary schools in the area. The constraints experienced by the researchers include the existence of uncontrollable variables, difficulty in ascertaining the level of sincerity of the respondents and possible exaggeration of their responses. The researchers were however objective throughout the entire process and assured respondents of their confidentiality and that their responses were to be used only for the purpose of the study. The findings of the study, therefore, need to be applied in other geographical locations but with caution.

\section{Results}

In this section, the research hypotheses formulated were tested and the results are as presented below.

Hypothesis 1: There is no significant influence of higher education needs on the development of displaced persons.

Table 1. Pearson Product Moment Correlation analysis of the influence of higher education needs on the development of displaced persons $(\mathrm{n}=600)$

\begin{tabular}{|c|c|c|c|c|c|c|c|c|c|}
\hline Variables & $\begin{array}{l}\sum \mathrm{x} \\
\sum \mathrm{y}\end{array}$ & $\begin{array}{l}\sum \mathrm{x}^{2} \\
\sum \mathrm{y}^{2}\end{array}$ & $\sum x y$ & $\overline{\mathrm{X}}$ & SD & df. & $\mathrm{R}$ & $\mathrm{t}$ & t-critical \\
\hline Higher education needs & 12,559 & 13004.06 & \multirow{2}{*}{$3,4494.13$} & 19.86 & 4.38 & \multirow{2}{*}{598} & \multirow{2}{*}{0.81} & \multirow{2}{*}{33.78} & \multirow{2}{*}{1.96} \\
\hline Development of displaced persons & 61,962 & $139,086.9$ & & 103.27 & 15.24 & & & & \\
\hline
\end{tabular}

*significant at 0.05 level of significance.

The result of the analysis gave a significant positive r-value of 0.81 . The mean score of higher education needs was 19.86 with SD of 4.38 while the mean score of development of displaced persons was 103.27 with SD of 15.24. To test for the statistical significance of the outcome, the r-value was converted to t-value of 33.78 at 0.05 level of 
significance with 598 degrees of freedom. It was observed to be greater than the critical t-value of 1.96 .

Consequently, the null hypothesis was rejected and the alternate hypothesis retained. The result implies that there is a highly significant influence of higher education needs on the development of displaced persons. This also suggests that displaced persons will exhibit significant positive attitude towards self and community development if their higher education needs are met. The more their higher education needs are met the more development they will experience and vice versa.

Hypothesis 2: Award of scholarships/bursaries does not significantly influence displaced persons' access to higher education.

Table 2. Pearson Product Moment Correlation analysis of the influence of scholarships/bursary awards on access to higher education of displaced persons $(\mathrm{n}=600)$

\begin{tabular}{|c|c|c|c|c|c|c|c|c|c|}
\hline Variables & $\begin{array}{l}\sum \mathrm{x} \\
\sum \mathrm{y}\end{array}$ & $\begin{array}{l}\sum \mathrm{x}^{2} \\
\sum \mathrm{y}^{2}\end{array}$ & $\sum x y$ & $\overline{\mathrm{X}}$ & SD & df. & $\mathrm{r}$ & $\mathrm{t}$ & t-critical \\
\hline Scholarships/bursary awards & 11940 & 4488.66 & \multirow{2}{*}{$21,245.43$} & 19.90 & 4.02 & \multirow{2}{*}{598} & \multirow{2}{*}{0.58} & \multirow{2}{*}{17.41} & \multirow{2}{*}{1.96} \\
\hline Access to higher education of displaced persons & 61,962 & $139,086.9$ & & 103.27 & 15.24 & & & & \\
\hline
\end{tabular}

*significant at 0.05 level of significance.

From Table 2 we can see that the outcome of the test yielded a positive r-value of 0.58 . The mean score of higher education needs was 19.90 with SD of 4.02 while the mean score of development of displaced persons was 103.27 with SD of 15.24. To test for the statistical significance of the outcome, the r-value was converted to t-value of 17.41. The value at 0.05 level with 598 degrees of freedom was observed to be greater than the critical $t$-value of 1.96. The calculated t-value was seen to be much higher than the critical t-value of 1.96 . The result gave enough evidence to reject the null hypothesis. The alternate hypothesis was therefore retained. The result indicates that there is a significant influence of scholarships/bursary awards on access to higher education of displaced person. It may therefore be inferred that the more scholarships/bursary awards provided the better the chances of displaced persons gaining access to higher education.

Hypothesis 3: Provision of distance learning and e-learning opportunities do not significantly influence displaced persons' access to higher education.

Table 3. Pearson Product Moment Correlation analysis of the influence of distance learning and e-learning opportunities on access to higher education of displaced persons $(n=600)$

\begin{tabular}{cccccccccc}
\hline Variables & $\begin{array}{c}\sum \mathrm{x} \\
\sum \mathrm{y}\end{array}$ & $\begin{array}{c}\sum \mathrm{x}^{2} \\
\sum \mathrm{y}^{2}\end{array}$ & $\sum \mathrm{xy}$ & $\overline{\mathrm{X}}$ & $\mathrm{SD}$ & $\mathrm{df}$. & $\mathrm{R}$ & $\mathrm{t}$ & $\mathrm{t}$-critical \\
\hline Scholarships/bursary awards & 11,934 & 6927.96 & 24823.23 & 19.89 & 4.47 & \multirow{2}{*}{59.68} & \multirow{2}{*}{22.68} & \multirow{2}{*}{1.96} \\
\hline Access to higher education of displaced persons & 61,962 & $139,086.9$ & & 103.27 & 15.24 & &
\end{tabular}

*significant at 0.05 level of significance.

The result in Table 3 above shows that the test yielded a positive r-value of 0.68 . The mean score of higher education needs was 19.89 with SD of 4.47 while the mean score of development of displaced persons was 103.27 with SD of 15.24. To test for the statistical significance of the outcome, the r-value was converted to t-value of 22.68 and tested at 0.05 level with 598 degrees of freedom. It was observed to be greater than the critical t-value of 1.96. The calculated t-value (22.68) was seen to be much higher than the critical t-value of 1.96. This implies that the result is significant. With this result the null hypothesis was rejected and the alternate hypothesis was therefore retained. This implies that distance learning and e-learning opportunities have significant positive influence on access to higher education of displaced person. It may therefore be inferred that the higher the chances of distance learning and e-learning opportunities provided the higher the chances of displaced persons gaining access to higher education.

\section{Discussion}

Hypothesis 1 was meant to establish whether or not higher education needs influence development of displaced persons. The positive significance indicates that respondents agreed that higher education needs influence development of displaced persons. The reason for this might be attributed to the fact that displaced persons need to 
update their knowledge, acquire skills so as to meet with the current needs of globalized world. This position corroborated with the position canvassed by Lowe (2019), Parater (2015) and UNHCR Education Report (2016) that access to higher education help displaced persons gain skills needed for economic self-sufficiency and recovering a sense of purpose and dignity, peace building and stability, creation of businesses and social enterprises, or building infrastructure and lobby for improvements to public services at a local, national and regional level.

Hypothesis 2 focused on determining whether or not award of scholarship/bursaries exert a significant influence on access to higher education of displaced persons. The result in Table 2 revealed that there is a significant positive influence of award of scholarships/bursaries on access to higher education of displaced persons. This finding agrees with Cosentino, Fortson, Liuzzi, Harris, and Blair (2019), El-Sheikh ( 2017) and Bergan (2015) who stated that scholarships close the educational gap, offer sustainable access, is central in enabling young people in displaced communities continue studies beyond primary and secondary education and is a key tool in increasing access to higher education. They insisted that providing scholarships is an effective way to improve/ increase participation in tertiary education as well as promote social mobility among vulnerable, disadvantaged, and underserved youth in developing countries.

Hypothesis 3 sought to establish the influence of certified distance learning and e-learning opportunities on access to higher education for displaced persons. The result of the analysis was significant. Thus the null hypothesis was rejected and the alternate retained. The result in table 3 revealed that respondents agreed that provision of certified distance learning and e-learning opportunities influence access to higher education among displaced persons. This finding is in agreement with Ambe-Uva (2012), Halkic and Arnold (2019) and MENA (2016) that distance learning e-learning opportunities has the potential to deliver educational content at very low cost virtually anywhere especially to displaced persons and is promoted as a solution for the integration of disadvantaged groups into higher education anda key strategy for increasing access to higher education. They maintained that these approaches are used to provide access to displaced persons and enables students living under-resourced areas to connect with higher education opportunities and to exchange knowledge globally.

\section{Conclusion}

Higher education of any nation is responsible for its national development. The growth and development of displaced persons lies on proper identification and recognition and effective management of higher education needs. The findings revealed that award of scholarship/bursaries and provision of distance learning and e-learning will significantly enhance access to higher education. The need for higher education is acute in places of conflict and is crucial in rebuilding societies and maintaining stability. Higher education is strongly linked to increased opportunity, strengthened economic development, improved public health and safer communities. It offers young people hope and a path towards a sustainable and independent future. This level of education opens the door for all citizens to participate in developmental activities and when citizen are denied education, they are excluded from the development process, which in turn puts them at a disadvantage vis-a-vis their compatriots with the benefits of education. This is why there should be an emphasis on access to good quality higher education for displaced persons. The extent to which education stands on the same wavelength with the needs of society is the strongest measure of its relevance.

\section{Recommendations}

Based on the findings, the following recommendations were made:

1) Government should show commitment in diagnosing and managing higher education needs of displaced persons. Apart from addressing basic resettlement requirements for displaced persons, there is need for the government to coordinate efforts towards meeting their higher education needs by enabling them to enroll in higher education programmes.

2) The government should sensitize the displaced persons on accessibility of government initiated scholarship/bursary schemes and how it can supplement students' school fees. Public corporations, industries and good spirited individuals, should be encouraged to offer scholarship programmes to indigent displaced youths in order to expand access to higher education and bridge the educational gap. Also, the managers of government owned higher educational institutions should be mandated to create chances for admission to displaced youth who are seeking places in tertiary institutions.

3) It is important to have requisite distance learning and e-learning facilities, but these should be coupled with ensuring all stakeholders are properly enlightened on the use of such facilities. Government should ensure provision of basic resources like books, computers, classrooms, libraries, electricity, in the displaced persons 
camps in order to create an enabling environment for the smooth take-off of e-learning process. She should collaborate with other agencies like Inter-Agency Network for Education in Emergencies (INEE) that leverage information technology to deploy accessible educational technologies that will enable displaced persons access higher education.

4) A similar study should be undertaken covering other variables and other IDPs groups in Nigeria that were not covered by this study and using a different methodology. This is needed to substantiate and extend the breath of findings regarding higher education needs of internally displaced persons.

\section{Acknowledgements}

The authors are deeply indebted to the various authorities whose works were cited and which provided a guide to this study. They are equally grateful to all students and teachers of the three secondary schools who willingly participated in this study and the research assistants for gathering relevant data.

\section{References}

Ajayi, I. G., \& Awodiji, O. A. (2016). Managing educational needs of internally displaced persons for sustainable development in Nigeria: The way forward. JPSD, 2(1), 117-131.

Altbach, P. G., Reisberg, L., \& Rumbley, L. (2009). Trends in global higher education: Tracking an academic revolution. Boston: Center for International Higher Education. https://oi.org/10.1163/9789004406155

Ambe-Uva, T. N. (2012). The right to education for internally displaced persons in Nigeria through Open and Distance Learning. Huria: Journal of the Open University of Tanzania, 13(2), 359-372.

Bergan, G. (2015). Why education is a life-saving sector for refugees. Retrieved from https://www.esu-online.org/news

Cosentino, C., Fortson, J., Liuzzi, S., Harris, A., \& Blair, R. (2019). Can scholarships provide equitable access to high-quality university education? Evidence from the Mastercard Foundation Scholars Program. $\begin{array}{lllll}\text { International Journal of } & \text { Educational } & \text { Development, } & 71, & \end{array}$ https://doi.org/10.1016/j.ijedudev.2019.102089

Delgado, M. (2008). The role of universities in peace building process in context of armed conflict. The experience of univeridad de Bogota Jorge Tadeo Lozana in Colombia. Proceedings of the 4th International Barcelona conference on Higher Education (Vol. 5). The role of higher education in peace building and reconciliation processes. Retrieved from http://www.gunirmies.net

El-Sheikh, S. (2017). Higher education in crisis situations: Synergizing policies and promising practices to enhance access, equity and quality in the Arab Region. The Regional Conference on higher education In Crisis Situations, Egypt, 28-29 March 2017Conference Report Mai 2017.

Federal Republic of Nigeria. (2012, August). National Policy on Internally Displaced Persons (IDPs) in Nigeria.

Ferris, E., \& Winthrop, R. (2010). Education and displacement: Assessing conditions for refugees and internally displaced persons affected by conflict. Background Paper for the Global Monitoring Report. The Brookings Institution.

Gladwell, C., Hollow, D., Robinson, A., Norman, B., Bowerman, E., Mitchell, J., ... Hutchinson, P. (2016). Higher education for refugees in low-resource environments: Landscape review. Jigsaw Consult, United Kingdom.

Grisanti, E. (2019). Higher education for displaced women: A defense against human trafficking. IIPEER.

Halkic, B., \& Arnold, P. (2019). Refugees and online education: student perspectives on need and support in the context of (online) higher education. Journal Learning, Media and Technology, 44(3), $346-364$. https://doi.org/10.1080/17439884.2019.1640739

INEE. (2016). Education for a better future-creating prospects for displaced populations. Berlin, Germany.

INEE. (2019). Tertiary education in emergencies. Retrieved from https://archive.ineesite.org

Internal Displacement Monitoring Centre (IDMC). (2019). Annual conflict and disaster displacement figures. Nigeria IDMC. Retrieved from https://www.internal-displacement.org

Lim, M., Murray, R., \& Laera, A. (2019). Removing barriers for displaced academics. Angle Journal. Retrieved from http://anglejournal.com/article/2019-09-removing-barriers-for-displaced-academics/

Lowe, S. (2019). A bridge to the future: From higher education to employment for displaced youth in Africa. 
World University Service of Canada for MasterCard Foundation.

Lunette, C. (2016). University students from refugee background. Why should we care? Higher Education Research and Development, 35(6), 1311-1315. https://doi.org/10.1080/07294360.2016.1190524

Marko, K. (2018). Equitable access to quality education for internally displaced children. UNICEF Somalia Country Office: Cooperation International CAR.

Marko, K. (2018). Equitable access to quality education for internally displaced children. UNICEF Somalia Country Office: Cooperation International CAR.

MENA. (2016). ICT and the education of refugees: A Stocktaking of Innovative Approaches in the MENA Region Lessons of Experience and Guiding Principles. Education Global Practice MENA (GED05)-World Bank Documents.

Milton, S., \& Barakat, S. (2016). Higher education as the catalyst of recovery in conflict affected societies. High Quality Technical Assistance for Results (HEART). https://doi.org/10.1080/14767724.2015.1127749

Moser-Mercer, B., Hayba, E., \& Goldsmith, J. (2016). Higher education spaces and protracted displacement: How learner-centered pedagogies and human-centered design can unleash refugee innovation. UNESCO 2016: Technologies for Development (pp. 41-52). https://doi.org/10.1007/978-3-319-91068-0_4

Okwute, A. O., Sanda, A., \& Usman, M. (2017). Community development in emergency situation: A case study of internally displaced persons in Borno State. International Journal of Education and Research, 5(6), 209-224.

Parater, L. (2015). 10 ways to innovate in higher education in emergencies. UNCHR Innovation Service.

The Catalyst Foundation for Universal Education. (2012). New platform currently offering $600+$ scholarships and programs for displaced university students. JUSOOR.

UNHCR Education Report. (2016). Aiming Higher-The other one per cent. Retrieved from http://www.unhcr.org

UNHCR. (2020). Nigeria emergency. Retrieved from https://www.unhcr.org

United Nations High Commission for Refugees. (2016). No more excuses: Provide education to all forcibly displaced people. Policy Paper 26.

United Nations Human Rights Office of High Commissioner. (2016). Questions and answers about IDPs. Retrieved from https://www.ohchr.org/EN/Issues/IDPersons/Pages/Issues.aspx

Usang, E. E., Ikpeme, N. J., \& Amimi, P. B. (2014). Challenges of mobilization and participation for community development: A study of the internally displaced person of Bakassi Peninsular, Nigeria. Journal of Education and Practice, 5(7), 158-165.

World Bank. (2018). Ground Swell: Preparing for Internal Climate Migration.

\section{Copyrights}

Copyright for this article is retained by the author(s), with first publication rights granted to the journal.

This is an open-access article distributed under the terms and conditions of the Creative Commons Attribution license (http://creativecommons.org/licenses/by/4.0/). 